\title{
Employee Stock Options, Financing Constraints, and Real Investment: Theory and Evidence
}

\author{
Ilona Babenko, Michael Lemmon, and Yuri Tserlukevich*
}

\begin{abstract}
In this paper, we demonstrate the advantage of broad-based stock option plans over cash compensation when the firm needs to finance both current and future investment in an environment where external finance is costly. Intuitively, the company obtains funds for investment in the current period by cutting fixed wages through the issuance of stock options. The company receives additional funds in later periods when it collects the cash proceeds and tax savings from option exercises. Importantly, the cash inflow arising from option exercises is correlated with improvements in the firm's investment opportunities, thus providing funds in precisely those states of the world where the demand for investment is high. Option grants in the current period therefore allow the firm to relax both its current and future financing constraints and to increase investment in positive NPV projects. Consistent with the predictions of the model, we estimate that firms increase investment by $\$ 0.38$ for each dollar of proceeds received from the exercise of stock options, and that the sensitivity of investment to proceeds from option exercises is higher in firms likely to face financing constraints.
\end{abstract}

\footnotetext{
*Babenko is with the Department of Finance, Hong Kong University of Science and Technology, Clear Water Bay, Kowloon, Hong Kong, babenko@ust.hk. Tel. +852-23587679. Lemmon is with the University of Utah, Eccles School of Business, finmll@business.utah.edu, Tel (801) 585-5210. Tserlukevich is with the Department of Finance, Hong Kong University of Science and Technology, yuri@ust.hk, Tel. +852-23588016.
} 


\section{Introduction}

The use of broad-based employee stock option plans grew tremendously during the 1990's. According to Hall and Murphy (2003), in aggregate, the value of stock options granted by U.S. companies to their employees grew from around $\$ 11$ billion in 1992 to over $\$ 119$ billion in 2000. When previously granted options are exercised, there is an inflow of funds to the firm that can be allocated to investment or other uses. These cash flows can be substantial. For example, in 2004, Amgen Corporation received over $\$ 450$ million from proceeds associated with the exercise of employee stock options as well as an additional $\$ 200$ million in corresponding tax benefits. The cash inflows associated with option exercises were nearly 50\% of Amgen's total capital expenditures for the year. Although the growth in broad-based option plans has led to proceeds from stock option exercises becoming one of the largest items on the cash flow statement for many firms, the extent to which these cash flows affect firm investment and financing policies has received little attention in the academic literature.

Building on insights from real options theory, we demonstrate the advantage of stock options over cash compensation when the firm needs to finance both current and future investment in an environment where external finance is costly. Intuitively, the company obtains funds for investment in the current period by cutting fixed wages through the issuance of stock options. The company receives additional funds in later periods when it receives the cash proceeds and tax savings from option exercises. Importantly, the cash inflow arising from option exercises is correlated with improvements in the firm's investment opportunities, thus providing funds in precisely those states of the world where the demand for investment is high. Option grants in the current period therefore allow the firm to relax both its current and future financing constraints and to increase its investment. 
To highlight the effect of stock options on investment, we build a simple two-period model of investment under capital constraints. Our model is similar to that of Almeida, Campello and Weisbach (2004) who examine the effect of financing constraints on the relationship between cash flow and savings. We extend the insights from their model to examine the effect of compensation choice on investment and saving policies in the presence of costly external financing when firms face variable investment opportunities across states. The optimal compensation structure trades off the premium that employees require to receive options in lieu of fixed wages against the benefits of relaxing financing constraints.

Several important results emerge from the model. First, we show that a financially constrained firm can take on larger investments by using more stock options for compensation. Stock options relax financing constraints because, in contrast to fixed wages, paying with options requires no immediate cash outflow and, in addition, generates a cash inflow at the time the options are exercised. In contrast, investment of a financially unconstrained firm is not affected by the compensation mix of the firm's employees. Second, we show that the effects of stock options and precautionary savings in relaxing financing constraints are important when agency problems leading to overinvestment exist. Paying with stock options can reduce overinvestment by managers because stock options provide cash only in high investment demand states thereby allowing the firm to reduce its precautionary savings and to minimize the amount of excess cash available to the manager in states with poor investment opportunities.

We examine the predictions of the model using data on firms in the options database published by the Investor Responsibility and Research Center (IRRC). The database contains data on the outstanding, granted, and exercised options for firms in the S\&P 500 over the period 1999 through 2004. In addition, 
we expand our sample by collecting data on the NASDAQ 100 firms. The use of stock options by firms in our sample is substantial. On average, the number of shares associated with outstanding options is equal to $12.5 \%$ of total shares outstanding. Annual proceeds from option exercises and the associated tax benefits average $1.3 \%$ and $1.2 \%$ of beginning-of-period assets, respectively. The average level of capital investment and research and development (R\&D) expenditures for our sample firms are $6.2 \%$ and $3.4 \%$ of assets. Thus, the cash inflows associated with exercises of stock options are equivalent to about $25 \%$ of total investment spending on average.

To test the main prediction of our model, we estimate the sensitivity of investment to cash flows associated with option exercises controlling for Tobin's q and operating cash flow. We examine both R\&D and capital investment. Consistent with the predictions of the model, we find that investment is positively related to proceeds from stock option exercises. The results are strongest for $\mathrm{R} \& \mathrm{D}$ investment and for firms classified as financially constrained using a variety of measures. The findings highlight an additional benefit associated with option-based compensation that, to our knowledge, has not been studied in prior literature.

We also provide evidence on a competing hypothesis suggested by Bens, Nagar, and Wong (2002). These authors argue that managers concerned with the earnings-per-share dilution associated with equity-based compensation shift resources away from current investment in order to repurchase stock in response to the exercise of stock options by employees. In contrast to this prediction, we find no evidence that stock repurchases are correlated with the proceeds from option exercises.

Prior literature on the use of broad-based stock option plans has focused on the use of stock options to provide incentives, as a device to attract and retain 
qualified employees, and on the use of option grants as a substitute for cash compensation in financially constrained firms (e.g., Yermack (1995), Core and Guay (2001), and Oyer and Schaefer (2005a, 2005b)). Our analysis points out an additional benefit associated with option based compensation as a way of providing state contingent financing for investment. In addition, we add to the current debate regarding the efficacy of broad-based option plans. Our results suggest that the use of option-based compensation can provide a mechanism to relax financing constraints and increase real investment.

The remainder of this paper is structured as follows. Section I briefly describes the cash flow implications associated with option grants and provides a brief literature review. Section II presents the model and derives empirical predictions. Section III describes the data and Section IV presents empirical results. Section V concludes with a brief summary and some directions for future research.

\section{Background and literature review}

Employee stock options give employees a right to purchase a share of the company's stock at a stated exercise price prior to a contractually specified expiration date. A typical employee option grant has a maturity of ten years and is generally subject to a vesting schedule where $25 \%$ of the grant becomes exercisable each year following the grant date. Unlike tradeable options, employee stock options are non transferable. In contrast to cash wages, there is no cash outflow to the firm at the time of the option grant. At the time of exercise, however, the firm delivers shares of the firm's stock to the employee and receives from the employee a cash amount equal to the exercise price times the number of exercised options. ${ }^{1}$ These proceeds generally appear under cash flows

\footnotetext{
${ }^{1}$ We note that while some companies allow for cashless option exercise, our empirical results are largely unaffected by the choice of exercise method. Even with cashless option exercise,
} 
from financing activities in the statement of cash flows. There are no tax consequences at the time of the option grant, but at the time of the option exercise the company can take a deduction out of its taxable income equal to the number of options exercised multiplied by the difference between the stock price at exercise and the option strike price (see Hanlon and Shevlin (2001) for details). Prior research finds that employees generally exercise their options prior to the contractual expiration date and that the amount of options exercised is increasing in the firm's stock price (see Huddart and Lang (1996), Carpenter (1998), Heath, Huddart, and Lang (1999), Bettis, Bizjak, and Lemmon (2005)).

Much of the finance literature investigates the link between stock option grants and the incentives that they provide. While the provision of incentives is likely to be a major consideration for top executives it is more difficult to rationalize the use of broad-based option plans for lower level employees, whose actions have little direct influence on firm performance. Consistent with this view, Oyer and Schaefer (2005a) reject an incentives-based explanation for the use of broad-based option plans, and instead conclude that sorting and retention explanations are more consistent with the data (also see Ittner, Lambert, and Larcker (2003)). Similarly, Oyer (2004) argues that when employees' outside opportunities are correlated with the firm's stock price, the use of stock options helps to minimize renegotiation costs in the labor market. The surge in stock option awards has also been linked to declining corporate morale and to their favorable accounting treatment (Hall and Murphy (2003)). Other studies investigate the corporate tax implications of using stock options to compensate employees. For example, Graham, Lang, and Shackelford (2004) find that correctly accounting for ESO deductions lowers firms' marginal tax rates, while

firms usually pocket the proceeds and enjoy the corresponding tax benefits. In cashless option exercise, the company makes arrangements with a brokerage firm to loan the money needed to exercise the option to the employee and immediately sells part or all of the shares to repay this loan (Heath, Huddart, and Lang (1999)). 
Babenko and Tserlukevich (2007) show that stock options have a tax advantage over fixed wages and increase a firm's debt capacity.

Several existing papers investigate the link between stock option grants and financing constraints, suggesting that by substituting stock options for cash wages young cash-strapped firms can increase their available internal resources at the grant date. In support of this hypothesis, Yermack (1995) finds that companies facing liquidity constraints shift the mix of executive pay away from cash compensation and toward stock options, while Core and Guay (2001) document that stock options are granted more intensively to non-executives when firms have greater financing needs. As pointed out by Oyer and Schaefer (2005a), however, risk-averse employees will demand a higher return compared to betterdiversified investors to hold stock options, and therefore it is not clear that employees are the most efficient source of capital. Employees will be efficient providers of capital only when they are more optimistic than alternative investors or when the degree of information asymmetry between managers and outside investors is greater than that between managers and employees. Consistent with the former view, Bergman and Jenter (2007) find that firms use broad-based option compensation when employees are likely to be excessively optimistic about company stock and when options are preferred to traded equity, while the latter view is supported by evidence in Huddart and Lang (2003) who examine stock returns following option exercises and conclude that junior employees have at least as much price-relevant information as do top executives. Fama and French (2004) also suggest that issues of stock options to employees are prime candidates for mitigating the informational frictions that underlie the pecking order theory of capital structure.

It is important to note that we do not attempt to provide a complete theory of why firms grant employee stock options or why stock options would be 
a preferred form of financing compared to other possible financial instruments issued to outside investors. Instead we assume either that informational frictions between employees and the firm are smaller than those between the firm and outside investors or that other benefits of granting options (e.g., minimizing renegotiation costs as in Oyer (2004)) lead firms to grant stock options to employees. Doing so allows us to focus on the relationship between stock options and real investment decisions when firms face significant costs in accessing external capital markets.

In contrast to existing studies, we explicitly model the tradeoff between the premium that employees require to hold options and the benefits of relaxing financing constraints and focus on the effects of option grants on real investment decisions. We show that option grants act through two channels to relax financing constraints. The first is the well known idea that option grants substitute for cash compensation and increase internal cash flows at the grant date. The second channel is that option grants provide cash and tax benefits to the firm upon exercise. The fact that exercises occur when the firm has good investment opportunities allows the firm to increase investment in states of the world where the demand for investment is high. This latter effect has not to our knowledge been previously studied.

Finally, our analysis is also related to the literature on security design. Stein (1992) shows that firms issuing risky convertible bonds can credibly signal their quality to the market and, therefore, can issue external equity through a backdoor. Mayers (1998) shows that, by issuing convertible bonds firms can control overinvestment incentives and secure an additional round of funding only when performance is good. Stock options differ from convertible bonds because they provide state contingent financing without increasing the risk of default and the associated bankruptcy costs. In addition, unlike employee stock options, 
convertible bonds do not directly provide additional cash flow to the firm at the time of conversion, but instead allow firms to issue additional debt by injecting equity into the firm's capital structure at the time of conversion. In this regard, stock options are essentially warrants issued to employees. Sahlman (1990) discusses how venture capitalists control agency costs through the use of staged financing, while Schultz (1993) illustrates how warrants can provide staged financing while minimizing overinvestment. The extension of our model presented in Section II.B shows that employee stock options can play a similar role in mitigating overinvestment.

\section{Model}

In the model, we consider a firm that undertakes a multi-period investment under financing constraints. The basic setup is similar to the model in Almeida, Campello, and Weisbach (2004). We first state the assumptions of the model and describe the effects of financing constraints on investment. We then derive the optimal compensation and savings policies and show that using stock options to compensate employees can relax both current and future financing constraints and increase investment in positive NPV projects. Finally, we show that the firm can alleviate the overinvestment problem by cutting savings and increasing the number of stock options.

\section{A. Setup}

The model has three dates 0,1 , and 2. The demand for the firm's products affects both the cash flows from assets in place and the firm's investment opportunities and can be high or low at $t=1$ with corresponding probabilities $p$ and $1-p$.

The assets in place produce cash flows, $c_{0}$, at $t=0$ and cash flows, $c_{1}^{H}$ and 
$c_{1}^{L}$ at $t=1$, in the state with high and low demand, respectively. In addition, the firm can borrow amounts $B_{t}$ at $t=0$ and $t=1$ from the bank, subject to a collateral constraint. Savings, $C$, can be carried from $t=0$ to $t=1$. Investment can be made at dates $t=0$ and $t=1$, with all profits realized at date $t=2$. For simplicity, we set the risk free rate to zero.

The initial investment outlay of $I_{0}$ at $t=0$ generates cash flows, $F\left(I_{0}\right)$, at $t=2$. Similarly, investments $I_{1}^{H}$ or $I_{1}^{L}$ at $t=1$ generate cash flows $H\left(I_{1}^{H}\right)$ and $L\left(I_{1}^{L}\right)$ at $t=2$, respectively. We assume that the functions $F, H$, and $L$ are increasing and concave, $F^{\prime}\left(I_{0}\right)>0, F^{\prime \prime}\left(I_{0}\right)<0, H^{\prime}\left(I_{1}^{H}\right)>0, L^{\prime}\left(I_{1}^{L}\right)>0$, $H^{\prime \prime}\left(I_{1}^{H}\right)<0, L^{\prime \prime}\left(I_{1}^{L}\right)<0$, and satisfy

$$
H^{\prime}(I)>L^{\prime}(I) \quad \forall I
$$

The last assumption captures the idea that investment opportunities tend to correlate positively with cash flows from assets in place, i.e., investment opportunities are better in the high-demand state than in the low-demand state. ${ }^{2}$ To model financing constraints, we follow Almeida et al. (2004) and assume that a fraction, $q \in(0,1)$, of the invested amount can be pledged for collateral. ${ }^{3}$

\footnotetext{
${ }^{2}$ In contrast to Almeida, Campello, and Weisbach (2004), we assume no hedging mechanism is available that would eliminate the uncertainty across states. Note that hedging cash flows at date $t=1$ is suboptimal in our setup because profitability is positively correlated with investment opportunities. Froot, Scharfstein, and Stein (1993) show that, in this case, firms have incentives to leave at least some cash flows exposed to risk to ensure that profitable projects have sufficient financing. In fact, if the sensitivity of investment to profitability is high, it may be optimal to increase the risk by introducing nonlinear securities, such as options. Froot, Scharfstein and Stein show that some hedging may be optimal if the firm faces convex costs of external financing or a uniformly concave production function. Since we assume a rigid constraint on external financing and strictly increasing marginal productivity with profits, such effects are necessarily absent in our model and the optimal hedging ratio is therefore zero.

${ }^{3}$ As in Almeida, Campello, and Weisbach (2004), in this setup, $q$ is not directly linked to the degree of constraints.
} 
Therefore, the amount of debt that the firm can issue is bounded by:

$$
\begin{aligned}
B_{0} & \leq q I_{0} \\
B_{1}^{H} & \leq q I_{1}^{H} \\
B_{1}^{L} & \leq q I_{1}^{L} .
\end{aligned}
$$

We assume that the firm has $N$ outstanding shares at $t=0$ and issues $n$ stock options to its employees maturing at $t=1$. We assume that that the exercise price of the stock options is set between high and low (endogenous) stock prices at $t=1$, i.e., $K \subset\left(S^{H}, S^{L}\right)$, so that the options are only exercised in the high-demand state. ${ }^{4}$ A higher exercise price would imply (in our twostate model) that stock options have no value; and a lower price would imply that stock options are always exercised.

In addition to stock options, the firm pays to its employees fixed salaries, $w$, at $t=0$. Employees are assumed to be risk averse and view the high-demand state with a subjective probability, $z$, that is lower than the true probability, i.e. $z<p .{ }^{5}$ Since employees can obtain a competitive salary, $W$, if they leave the firm, the employee's participation constraint requires that

$$
w+z n\left(S^{H}-K\right) \geq W,
$$

where $K$ is the exercise price of the options and $S^{H}$ is the stock price in the high-demand state. The firm has discretion regarding the type of compensation, subject to the employee's participation constraint. ${ }^{6}$

\footnotetext{
${ }^{4}$ This requirement is satisfied for options issued at-the-money, assuming that dilution from the exercise of stock options is relatively small.

${ }^{5}$ Assuming that employees are risk averse allows us to avoid corner solutions where the firm pays all compensation with stock options.

${ }^{6}$ For simplicity, we assume that wages are only paid at $t=0$ and the new contract can be signed at $t=1$. A plausible alternative assumption is that equal wages can be paid at both dates $t=0$ and $t=1$ when stock options are exercised. The main implication of this assumption will be lower optimal savings.
} 
Given our assumption regarding the profitability of investment, the statecontingent ex-dividend stock prices at $t=1$ are:

$$
\begin{aligned}
& S^{H}(\text { exercise })=\frac{F\left(I_{0}\right)+H\left(I_{1}^{H}\right)-q I_{0}-q I_{1}^{H}}{n+N}>K, \\
& S^{L}(\text { no exercise })=\frac{F\left(I_{0}\right)+L\left(I_{1}^{L}\right)-q I_{0}-q I_{1}^{L}}{N}<K,
\end{aligned}
$$

and therefore the ex-dividend stock price at $t=0$ is

$$
S_{0}=p\left(S^{H}+d_{1}^{H}\right)+(1-p)\left(S^{L}+d_{1}^{L}\right),
$$

where $d_{1}^{H}$ and $d_{1}^{L}$ are the dividends to shareholders at $t=1$ in the high and low demand states, respectively.

For simplicity, we assume that the corporate tax structure is flat with a tax rate of $T$. There are no interest deductions associated with debt because of our assumption of zero interest rate. However, the compensation expense reduces the taxes paid by the firm at $t=1$ : the firm takes a deduction equal to the difference between the stock price and the strike price, multiplied by the number of exercised stock options. We assume no depreciation of investment. To economize on notation, cash flows, $c_{0}$ and $c_{1}^{s}$, and the payoffs from the investment $F, H$, and $L$ are given in after-tax dollars. We assume the following sequence of events when solving the problem. First, the optimal compensation structure, i.e. the mix between stock options and fixed wages, is determined by the firm's shareholders. Second, the shareholders decide how much savings to carry to the next period, $t=1$, and how much to invest initially at $t=0$. Finally, given the compensation mix and savings available from the previous period, the shareholders choose optimal investment at $t=1$. 


\section{B. Investment by constrained and unconstrained firms}

Shareholders maximize the expected value of all dividends with respect to compensation, investment, and savings. Note that the dividend $d_{1}^{H}$ enters the maximization problem net of the price of shares issued to employees, $n S_{H} \cdot{ }^{7}$

$$
\begin{aligned}
& \max _{n, w, C, I, B}\left\{d_{0}+p\left(d_{1}^{H}-n S^{H}+d_{2}^{H}\right)+(1-p)\left(d_{1}^{L}+d_{2}^{L}\right)\right\} \\
& \text { s.t. } d_{0}=c_{0}+B_{0}-C-I_{0}-w(1-T) \geq 0 \\
& d_{1}^{H}=c_{1}^{H}+C+B_{1}^{H}-I_{1}^{H}+\underbrace{n K}_{\text {option proceeds }}+\underbrace{n\left(S^{H}-K\right) T}_{\text {tax benefits }} \geq 0 \\
& d_{1}^{L}=c_{1}^{L}-I_{1}^{L}+C+B_{1}^{L} \geq 0 \\
& d_{2}^{H}=F\left(I_{0}\right)+H\left(I_{1}^{H}\right)-B_{0}-B_{1}^{H} \\
& d_{2}^{L}=F\left(I_{0}\right)+L\left(I_{1}^{L}\right)-B_{0}-B_{1}^{L} .
\end{aligned}
$$

For a firm that has free access to external capital, the collateral is not limited and constraints (9), (10), (11) are not binding. Since the firm is unconstrained, it takes the first-best level of investment regardless of the compensation structure.

Proposition 1 Investment of an unconstrained firm in both period 0 and period 1 is not sensitive to the mix of compensation between stock options and fixed wages.

All proofs are given in Appendix A.

For a financially constrained firm, the borrowing capacities, $B_{0}$ and $B_{1}^{H}$, are exhausted and constraints (2) and (3) are binding. To maximize its investment, the firm pays zero dividends at the initial date, $d_{0}=0$, and in the high-demand state, $d_{1}^{H}=0$. We assume, however, that the financing constraint is not binding at $t=1$ in the low-demand state because investment opportunities are poor and

\footnotetext{
${ }^{7}$ Issuing stock options reduces the value of dividends to the original shareholders since the number of shares increases. The equivalent approach would be to maximize the expected value of dividends per share, i.e., $\frac{d_{0}}{N}+p \frac{d_{1}^{H}+d_{2}^{H}}{N+n}+(1-p) \frac{d_{1}^{L}+d_{2}^{L}}{N}$
} 
the optimal level of investment is low in this state. ${ }^{8}$ Substituting the expressions for dividends in (8) and dropping the constant terms produces:

$F\left(I_{0}\right)-I_{0}-w(1-T)+p\left(H\left(I_{1}^{H}\right)-I_{1}^{H}-n\left(S^{H}-K\right)(1-T)\right)+(1-p)\left(L\left(I_{1}^{L}\right)-I_{1}^{L}\right)$.

After substituting the participation constraint (5) into (14), we can rewrite the maximization problem as

$$
\max _{w, C, I}\left\{F\left(I_{0}\right)-I_{0}-w\left(1-\frac{p}{z}\right)(1-T)+p\left(H\left(I_{1}^{H}\right)-I_{1}^{H}\right)+(1-p)\left(L\left(I_{1}^{L}\right)-I_{1}^{L}\right)\right\}
$$

From (9) and (10) and the assumption that in the low-demand state the constraint is not binding, the optimal investment levels are determined by:

$$
\begin{aligned}
& I_{0}^{*}=\frac{c_{0}-C-w}{1-q}, \quad L^{\prime}\left(I_{1}^{L *}\right)=1 \\
& I_{1}^{H *}=\frac{1}{1-q}\left(c_{1}^{H}+C+n K+n\left(S^{H}-K\right) T\right) .
\end{aligned}
$$

One can easily see from (17) that, holding savings policy fixed, investment in the high-demand state, $I_{1}^{H *}$, increases with the proceeds and tax benefits from the exercise of stock options.

To investigate the effect of the compensation mix on investment, we first consider how the budget constraints change with compensation policy and savings. To simplify the problem, we first consider the case without tax, $T=0$. The case with non-zero tax, that carries the same intuition, can be found in Appendix B.

\footnotetext{
${ }^{8}$ Note that this assumption is not crucial and all our results hold if the firm is also constrained in the low-demand state, as long as we assume that investment opportunities are better in the high-demand state than in the low-demand state.
} 
The first order condition with respect to savings, $C$, follows from (15):

$$
F^{\prime}\left(I_{0}\right)=(1-p) 1+p H^{\prime}\left(I_{1}^{H}\right)
$$

This expression says that an additional dollar of savings at $t=0$ at the cost of a marginal decrease in investment, $F^{\prime}\left(I_{0}\right)$, increases value the next period by $H^{\prime}\left(I_{1}^{H}\right)$ if it relaxes the financing constraint with probability $p$. Alternatively, with probability $1-p$, a dollar of savings does not relax the constraint and therefore is valued at $\$ 1$. We are interested in the effect of changing the compensation mix on the optimal savings policy. Totally differentiating condition (18) with respect to the number of options granted, $n$, yields:

$$
\frac{\partial C^{*}}{\partial n}=-\frac{F^{\prime \prime}\left(I_{0}\right) \frac{\partial w}{\partial n}+p H^{\prime \prime}\left(I_{1}^{H}\right) K}{F^{\prime \prime}\left(I_{0}\right)+p H^{\prime \prime}\left(I_{1}^{H}\right)} .
$$

To determine how savings are affected by compensation policy, note that $F^{\prime \prime}\left(I_{0}\right)$ and $H^{\prime \prime}\left(I_{1}^{H}\right)$ are negative since the functions $F$ and $H$ are concave. In addition, it follows from the participation constraint (5) that $\frac{\partial w}{\partial n}$ is negative. Therefore $\frac{\partial C^{*}}{\partial n}>0$ if

$$
F^{\prime \prime}\left(I_{0}\right) \frac{\partial w}{\partial n}>-p H^{\prime \prime}\left(I_{1}^{H}\right) K
$$

The left-hand side of this expression represents the direct effect of options on optimal savings, i.e., when stock options replace fixed wages at $t=0$, there is a greater amount of cash flows available at $t=0$ that allows for greater savings. The right-hand side represents the indirect effect - at the time of the exercise, $t=1$, the stock options provide an inflow of funds and therefore relax financing constraints at $t=1$ and decrease the need to carry savings from $t=0$ to $t=1$. Savings decrease with option compensation if the strike price, $K$, or the probability of the high-demand state, $p$, are relatively high.

Using the expression for the sensitivity of savings to the number of options, 
we can determine the sensitivity of investment to the number of options.

Proposition 2 For a financially constrained firm, investment in both period 0 and period 1 is increasing in the number of stock options granted to employees.

Intuitively, the sensitivity of initial investment to options, $\frac{\partial I_{0}}{\partial n}$, is positive because options replace salary and therefore relax the financing constraints at the time of the grant. The sensitivity of investment to options at $t=1, \frac{\partial I_{1}^{H}}{\partial n}$, is positive because cash inflows from the exercise of stock options relax financing constraints at the time of the exercise. Appendix B establishes similar results in the nonzero tax case. ${ }^{9}$

To determine how the optimal compensation structure is set in our framework, consider the first order condition of (15) with respect to $n$ :

$$
\left(F^{\prime}\left(I_{0}\right)-1\right) \frac{\partial I_{0}}{\partial n}+\left(H^{\prime}\left(I_{1}^{H}\right)-1\right) p \frac{\partial I_{1}^{H}}{\partial n}-\left(1-\frac{p}{z}\right) \frac{\partial w}{\partial n}=0
$$

The first two terms are positive and show that stock options relax financing constraints and allow the firm to increase its investment. The last term is positive because risk-averse employees require a premium for holding stock options in lieu of fixed wages. If employees are risk-neutral $(z=p)$, then the FOC of the maximization problem is strictly positive and a corner solution (all stock options) is obtained. If the firm is unconstrained and takes the first-best level of investment $\left(F^{\prime}\left(I_{0}\right)=1, H^{\prime}\left(I_{1}^{H}\right)=1\right)$, the optimal solution is to provide full insurance to employees by paying fixed wages. The solution is interior if employees are risk averse and the firm is financially constrained.

\footnotetext{
${ }^{9}$ In the nonzero tax case, stock options relax financing constraints even further in the high-demand state by allowing the firm to pay less taxes in this state. The nonzero tax case is more difficult to solve analytically because stock option tax deductions depend on stock prices, which are endogenous in the model.
} 


\section{Compensation structure and the overinvestment prob- lem}

In this section we extend the model to consider how stock-based compensation affects investment and savings policies when managers' incentives are not perfectly aligned with those of shareholders. In particular, we model the managerial incentives to overinvest. Jensen (1986) argues that executives have incentives to misallocate the firm's cash; Shleifer and Vishny (1990) suggest that negative NPV acquisitions and investments are often driven by the managerial entrenchment and easy access to cash. In addition, when managerial compensation is linked to firm size (Hall and Liebman (1998)), managers have incentives to grow their firms beyond their optimal sizes.

To capture overinvestment incentives in a tractable form, we assume that managers prefer to invest the maximum possible amount at $t=1$. We do not explicitly consider the overinvestment problem at $t=0$ because we assume that the firm is initially set up by the firm's shareholders. The shareholders choose the optimal investment, compensation, and savings policies at $t=0$ and delegate all future decisions to managers.

Note that, by construction, the financing constraint is already binding in the high-demand state, making it impossible for the manager to further increase investment, $I_{1}^{H}$. However, there is slack conditional on low demand. The manager will overinvest in the low-demand state up to the point that he runs out of funds, i.e. until investment will cause the constraints (4) and (11) to bind. Because of the overinvestment problem, the marginal profitability of investment falls below the marginal cost in the low-demand state,

$$
I_{1}^{L *}=\frac{c_{1}^{L}+C}{1-q}, L^{\prime}\left(I_{1}^{L *}\right)<1 .
$$


From (15), the first order condition with respect to $C$ is

$$
F^{\prime}\left(I_{0}\right)=(1-p) L^{\prime}\left(I_{1}^{L}\right)+p H^{\prime}\left(I_{1}^{H}\right)
$$

This condition says that saving an extra $\$ 1$ at $t=0$ decreases investment at this date and carries a cost of forgone marginal profit, $F^{\prime}\left(I_{0}\right)>1$. At the same time, an additional dollar of savings relaxes the budget constraint in the high-demand state, allowing for a larger investment, $I_{1}^{H}$, and increasing firm value by $H^{\prime}\left(I_{1}^{H}\right)>1$. With probability $(1-p)$, the additional dollar of savings increases value in the low-demand state by $L^{\prime}\left(I_{1}^{L}\right)<1$. Therefore, the optimal amount of savings sets the marginal profitability at $t=0$ equal to the expected marginal profitability at $t=1$. Next, we establish that investment in excess of the first-best level decreases optimal savings.

Proposition 3 Holding compensation policy fixed, with a more severe overinvestment problem (smaller $L^{\prime}$ ), the firm carries forward a lower amount of savings.

Finally, we show that the overinvestment problem generally increases the incentives to pay employees with stock options.

Proposition 4 If $p K>\frac{\left|F^{\prime \prime} \frac{\partial w}{\partial n}\right|}{\left|H^{\prime \prime}\right|}$, then with a more severe overinvestment problem (smaller $L^{\prime}$ ), the firm uses more stock options for compensation.

The intuition behind the proposition is that the cash inflows from option exercises are state contingent and only provide additional cash to the manager when investment opportunities are good. In contrast, savings are not state contingent and an increase in savings exacerbates the overinvestment problem in the low demand state when investment opportunities are poor. In general, the results in this section show that compensation and savings policies play an important role in curbing the overinvestment problem. 


\section{Data and summary statistics}

We obtain data on broad-based employee stock option programs from the Investor Responsibility Research Center (IRRC) for S\&P 500 firms during the period 2000-2005 (as defined by the year of the shareholder meeting). Some firms have only three years of coverage (either 2000-2002 or 2003-2005) in the IRRC data set, since the composition of the S\&P 500 index changes over time and firms may drop and enter the index, depending on their financial performance. To minimize sample selection bias, we collect the missing data on stock options by hand whenever possible. Since we are particularly interested in firms that are likely to face financing constraints, we also collect stock option data for firms that were in the NASDAQ 100 index on December 8, 2006, but were not a part of the S\&P 500 index. All stock option data are adjusted for stock splits. We exclude banks and financial institutions (SIC 6000-6999) from the sample. Our final sample contains 2,332 firm-year observations from 419 firms. The data on stock option programs comes from 10k statements filed with the Securities and Exchange Commission (SEC). Firms report data on the number of options granted, exercised, and cancelled each year, as well as the number of outstanding options at the end of the fiscal year. Firms also report the weighted average strike price for the options in each group. The data on stock options is merged with financial data from the Compustat database.

We measure the proceeds from stock option exercises in any given fiscal year as the number of stock options exercised during that year multiplied by the weighted average strike price of stock options exercised. In addition to collecting the strike price, the firm also receives tax benefits when options are exercised. If the firm is profitable, the tax benefit is equal to the firm's tax rate multiplied by the number of options exercised and by the difference between the stock price at exercise and the strike price. When the firm is unprofitable, 
the tax consequences associated with option exercise are more complicated (See Hanlon and Shevlin (2001) for details). To gauge the tax consequences arising from option exercises, we construct a measure of the tax benefits as the number of stock options exercised, multiplied by the expected marginal tax rate (see Graham (1996)) and by the difference between the end-of-year stock price and the weighted average strike price of exercised options. Our measure of the tax benefits is no doubt noisy because we do not know the actual stock prices at which options are exercised and because it is difficult to accurately measure the expected marginal tax rate that should be applied.

We also compute the value of new option grants as the Black-Scholes value of stock options granted during the fiscal year, where we use the expected option life of newly granted options, reported in the firm's 10-K, as the appropriate maturity of the option. The Black-Scholes value likely overstates the value of the option to the employee (e.g., Hall and Murphy (2002), Bettis, Bizjak, and Lemmon (2005)), and thus also overstates the cash savings to the firm due to the substitution of options for fixed wages. Since the risk premium demanded by employees for holding stock options in lieu of fixed wages depends on unobservable characteristics (e.g., employee risk aversion, employee financial wealth and the fraction of wealth invested in the firm's stock), we simply report the Black-Scholes value of the grants for illustrative purposes.

Summary statistics are reported in Table I. ${ }^{10}$ As seen in the Table, the firms in our sample are large. The average firm size based on book assets (data item 6 ) is $\$ 14$ billion. The median firm size is $\$ 5$ billion. Nevertheless, despite the large size of these firms, the usage of stock options is substantial. Outstanding

\footnotetext{
${ }^{10}$ We note that while some companies allow for cashless option exercise, our empirical results are largely unaffected by the choice of exercise method. Even with cashless option exercise, firms usually pocket the proceeds and enjoy the corresponding tax benefits. In cashless option exercise, the company makes arrangements with a brokerage firm to loan the money needed to exercise the option to the employee and immediately sells part or all of the shares to repay this loan (Heath, Huddart, and Lang (1999)).
} 
options average $12.5 \%$ of outstanding shares, and the mean Black-Scholes value of annual option grants is $\$ 315$ million. Average annual proceeds from option exercises are $\$ 76$ million and the associated tax benefits are $\$ 55$ million on average. We normalize the stock option variables and all other variables of interest by the beginning-of-year book assets. Option grants, proceeds from exercise and tax benefits average $5.9 \%, 1.3 \%$ and $1.2 \%$ of book assets, respectively. It is worth noting that the standard deviation of the scaled tax benefit variable is over twice as large as the standard deviation of the proceeds from exercise, which is consistent with our conjecture that our proxy for tax benefits contains a significant amount of noise. Nevertheless, the correlation between option proceeds and tax benefits is high with Pearson (Spearman) correlation coefficients of $0.68(0.86)$.

We consider three measures of firm investment: 1) capital expenditures (data item 128) 2) research and development (R\&D) expenses (data item 46) and 3) total investment, calculated as the sum of $\mathrm{R} \& \mathrm{D}$ and capital expenditures. Following Bizjak, Brickley, and Coles (1993), missing values of R\&D expenditures are set equal to zero. As reported in Table 1, capital expenditures average 6.2\% of book assets and R\&D expenditures average $3.4 \%$ of book assets. Total investment is $9.7 \%$ of book assets on average. Unlike many prior studies of investment that focus exclusively on capital expenditures, we also include R\&D investment. There are two reasons for doing so. First, R\&D is a significant component of investment spending for the firms in our sample, representing about one-third of total investment spending on average. Second, as suggested by Himmelberg and Petersen (1994), R\&D investment should be particularly affected by financing constraints. Investment in R\&D is highly firm-specific and has a low collateral value, making it more difficult for the firm to secure debt financing for such projects. ${ }^{11}$ Additionally, adverse selection problems are also likely to be partic-

\footnotetext{
${ }^{11}$ Barclay, Morellec, and Smith (2006) demonstrate that the debt capacity of firms with
} 
ularly acute for investment in $\mathrm{R} \& \mathrm{D}$, thus increasing the cost of outside equity financing as well (e.g., Myers and Majluf (1984)).

Finally, we also measure share repurchase activity. Bens, Nagar, and Wong (2002) argue that managers are focused on avoiding dilution of earnings per share and that they divert funds from investment in order to repurchase shares in response to option exercises. Share repurchases (data item 115) are $3.3 \%$ of book assets on average, indicating that share repurchases represent a significant use of funds. Overall, the cash inflow from stock options at the time of exercise (sum of option proceeds and tax benefits) is sufficient to finance approximately $26 \%$ of total investment or $75 \%$ of repurchase activity on average.

As is standard in the financing constraints literature, we control for nonoption related cash flow. We measure non-option cash flow as net income before extraordinary items (data item 18) plus depreciation and amortization (data item 14) plus R\&D expense (data item 46). Following Himmelberg and Petersen (1994), we add back R\&D expense to the non-option cash flow because $R \& D$ is expensed for accounting purposes. Non-option cash flow averages $15.4 \%$ of book assets in our sample.

We also control for the firm's investment opportunities using the average Tobin's Q measure. Average Q is constructed as the market-to-book ratio of the firm's assets, where the market value of assets is equal to the market value of equity (data item $199 \mathrm{x}$ data item 25) plus the book value of assets (data item 6) minus the book value of equity (data item 60) and deferred taxes (data item 74). The average value of Tobin's $\mathrm{Q}$ in our sample is 2.69 and the median value is 1.85 .

Panels B and C report data separately for high and low option users defined by splitting the sample at the median value of outstanding options as a fraction

growth options is limited by the underinvestment problem. Tserlukevich (2007) argues that the offsetting tax benefits of debt are also small for firms with growth options. 
of shares outstanding. For high option users, outstanding options average 19\% of shares outstanding, while for low option users the corresponding value is $5.7 \%$. A few other distinctions between the two groups are notable. For the group of high option users, investment in R\&D is nearly $50 \%$ of total investment compared to about $21 \%$ for low option users. In addition, for the group of high option users, proceeds from option exercises and the associated tax benefits are sufficient to fund $35 \%$ of total investment on average compared to only $14 \%$ for low option users. For high option users, expenditures for stock repurchases are approximately equal to the sum of proceeds from exercise plus tax benefits, whereas, for low option users, repurchase expenditures substantially exceed the cash inflows associated with option exercise. Finally, the high option users are smaller, but have higher Tobin's Q values and higher non-option cash flows on average compared to low option users.

\section{Empirical analysis}

Although the model yields a number of results, we focus our empirical analysis on the predictions in Proposition 2 that relate the use of option based compensation to investment. The model delivers two main predictions regarding the relationship between investment and the use of stock options in financially constrained firms. The first prediction is that investment is positively related to option grants because options substitute for cash compensation thus freeing up funds for investment. The idea that option grants may substitute for cash compensation has been examined previously in a number of papers. For example, Yermack (1995) finds that option grants to executives are related to measures of cash constraints, while Core and Guay (2001) document that stock option grants to non-executive employees are related to the firm's funding needs. Kato,

Lemmon, Luo, and Schallheim (2005) find some evidence that option grants are 
related to cash constraints using Japanese data. The second, and more novel, prediction of our model is that proceeds and tax benefits arising from exercises of previously granted stock options provide state contingent cash inflows to firms that relax financing constraints in the period when exercise occurs. As mentioned previously, measuring the extent to which option grants substitute for cash compensation is difficult because measuring the value of the options to employees relies on a number of factors that are not observable, thus complicating tests of the first hypothesis. Because of this our analysis focuses on the second prediction.

In our empirical tests, we investigate whether firms tend to finance investment using the proceeds and tax benefits associated with option exercises. To the extent that external financing is costly, we expect a positive relationship between investment and cash inflows from stock option exercises after controlling for investment opportunities and non-option related cash flow. Specifically, we estimate the sensitivity of investment to option exercise related cash flows using regression specifications as follows:

$$
\begin{aligned}
\frac{I_{i t}}{A_{i, t-1}}= & \alpha_{i}+\alpha_{t}+\beta_{1} \frac{\text { Non-Option } C F_{i t}}{A_{i, t-1}}+\beta_{2} Q_{i, t-1} \\
& +\beta_{3} \frac{\text { Option Proceeds } s_{i t}}{A_{i, t-1}}+\varepsilon_{i t} \\
\frac{I_{i t}}{A_{i, t-1}}= & \alpha_{i}+\alpha_{t}+\beta_{1} \frac{\text { Non-Option } C F_{i t}}{A_{i, t-1}}+\beta_{2} Q_{i, t-1} \\
& +\beta_{3} \frac{\text { Option Proceeds } s_{i t}}{A_{i, t-1}}+\beta_{4} \frac{\text { Tax Benefits }}{\text { Tat }_{i, t}}+\varepsilon_{i t} .
\end{aligned}
$$

The regression specifications include firm fixed-effects to account for any unmodeled time invariant heterogeneity in firms' contracting environments and year fixed effects to account for any unmodeled macroeconomic effects that affect both investment and option exercises. For example, firms with managers of higher ability may expand their businesses at a faster rate and may also employ 
more option-based compensation. These firms will also likely have better stockprice performance and higher cash inflows from option exercises. Likewise, an aggregate market downturn may adversely affect both investment and option exercises.

Another concern with these types of regressions is the potential for a spurious correlation between investment and cash flow arising from misspecification of the empirical model or the fact that the proxy for investment opportunities (Tobin's Q) is measured with substantial error (Erickson and Whited (2000)). To deal with this issue, we rely on an empirical strategy similar to the one employed by Rauh (2006) in his analysis of the response of investment to mandatory pension contributions that shares features of the regression discontinuity approach used in labor economics (e.g., Van der Klaauw (1996), Angrist and Lavy (1999), and Angrist and Krueger (1999)). In our setting, we use the fact that cash inflows from option exercises are discontinuous at the point where the options fall out of the money. The identifying assumption is that the relationship between investment opportunities and the moneyness of the firm's outstanding options does not have the same nonlinearities and discontinuities as the function that relates the moneyness of the firm's options to the proceeds from option exercise. Thus, by including linear and nonlinear functions of the moneyness of the firm's outstanding options in the regression specifications above we are able to isolate the direct response of investment to the cash flows from option exercises.

The results of the regressions are presented in Table II. Statistical significance is assessed based on standard errors adjusted for clustering by firm and p-values are reported in parentheses below the coefficient estimates. Overall, the results are consistent with our prediction that investment is positively related to cash inflows from stock option exercises. The first three columns in the Table report the results for total investment, capital expenditures and R\&D, 
respectively. Similar to other studies of investment cash flow sensitivity, investment is positively related both to Tobin's Q and to non-option related cash flow. The coefficient estimate on non-option cash flow reported in the first column indicates that $\$ 0.19$ ( -value $<0.01)$ of each dollar increase in non-option cash flow is allocated to increasing total investment. The effect of proceeds from option exercises on investment is nearly twice as large. The coefficient estimate indicates that $\$ 0.38$ ( $\mathrm{p}$-value $<0.01$ ) of each dollar of proceeds received from option exercises is allocated to increasing total investment. The second and third columns of the table report the results for capital expenditures and R\&D, respectively. The effect of exercise proceeds on capital expenditures is smaller than the effect on $R \& D$ investment. The coefficient estimates indicate that $\$ 0.19$ ( $\mathrm{p}$-value $=0.08$ ) of each dollar of option exercise proceeds is allocated to capital investment, while $\$ 0.27$ ( $\mathrm{p}$-value $<0.01$ ) of each dollar of proceeds is used to increase R\&D spending.

Several papers establish that option-intensive firms initiate share repurchase programs in order to counteract the dilution from stock options (Kahle (2002); Bens, Nagar, Skinner, and Wong (2003); and Brav, Graham, Harvey, and Michaely (2005)). Bens, Nagar, and Wong (2002) go further and suggest that managers concerned with dilution of earnings per share from option exercises will actually divert funds from profitable investment in order to repurchase stock. This argument implies that option exercises and stock repurchases should be positively correlated all else equal. The regression results reported in the fourth column of the table examine this conjecture. The coefficient estimate on option exercise proceeds when stock repurchases are the dependent variable in the regression is negative and is not statistically significant $(\mathrm{p}$-value $=0.60)$. While we agree that firms with more outstanding options do repurchase more stock, our results indicate that repurchases are not directly related to option exercises. 
Instead, taken together with our results for investment, firms appear to buy back stock with funds that remain after the desired amount of investment is made. This finding is also consistent with the survey results in Brav, Graham, Harvey, and Michaely (2005) who find that approximately $80 \%$ of managers agree or strongly agree that they make repurchase decisions after their investment plans are determined. In addition, most managers believe that there are no negative consequences to scaling down or cancelling repurchase programs. ${ }^{12}$

The fifth column in the table reports results when variables measuring the average moneyness of the firm's outstanding options and its square are added to the regression to control for any unmodeled relationship between investment opportunities and moneyness. Adding controls for moneyness decreases the coefficient estimate on option exercise proceeds only slightly to $\$ 0.33$ (p-value $=0.03)$, suggesting that we have accurately isolated the direct effect of exercise related cash flows on investment.

Finally, the last two columns in the table examine how cash flows from tax benefits associated with option exercise affect the results. The sixth column includes our measure of the tax benefits associated with option exercises as an additional explanatory variable in the regression. The coefficient estimate on the tax benefit variable is positive, but suggests that only $\$ 0.07$ (p-value $=0.09)$ from each dollar of tax benefits is associated with increased investment. Adding the tax benefit variable also slightly decreases the coefficient estimate on the option proceeds variable from $\$ 0.38$ to $\$ 0.34$ and increases its standard error. The final column reports results when we replace the proceeds variable with the sum of proceeds and tax benefits as a measure of the total cash inflow from option exercises. The coefficient estimate on this variable indicates that $\$ 0.11$ (p-value $<0.01$ ) of each dollar of the total cash inflow from option exercises (proceeds

\footnotetext{
${ }^{12}$ Our findings are also broadly consistent with the discussion by Hong, Wang, and Yu (2007) who suggest that financially constrained firms do not engage in repurchases.
} 
plus tax benefits) is allocated to investment. We expect that the coefficient estimate on the tax benefit variable will be biased downward due to our inability to accurately measure the cash inflows related to the tax benefits associated with option exercise, and thus represents a lower bound on the estimate of the effect of the related cash flows on investment.

In Table III, we report regressions of total investment on Tobin's Q, nonoption cash flow, and proceeds from option exercise for subsamples of firms defined using various measures of financial constraints. Firms that are not financially constrained should show no relationship between investment and proceeds from option exercises, while for financially constrained firms the sensitivity of investment to option exercise cash flows should be positive. We use several measures of financial constraints that have been used elsewhere in the literature. The results in the table are consistent with our hypothesis. The analysis focuses on the base regression specification for column 1 in Table 2 .

The first two rows of the table report results based on firms that do not pay dividends (constrained firms) and those that do. For both groups of firms, investment is positively related to non-option cash flow and $\mathrm{Q}$, and the coefficient estimate on non-option cash flow is larger for the group of dividend paying firms, which is consistent with Kaplan and Zingales (1997), Cleary (1999), and Moyen (2004). For non-dividend paying firms, the coefficient estimate on option exercise proceeds indicates that $\$ 0.47(\mathrm{p}$-value $=0.03$ ) of each dollar of exercise proceeds is allocated to investment. For dividend paying firms, the coefficient estimate on option exercise proceeds is $\$ 0.18$ and is not statistically significant. The next two rows in the table report results for groups of firms split by whether or not the firm has an investment grade bond rating (BBB or above). The results are similar to those reported based on dividend payout. For firms without an investment grade rating (constrained firms), $\$ 0.44$ of each dollar of exercise 
proceeds is used to increase investment. For firms with investment grade ratings, the relationship between investment and option exercise proceeds is $\$ 0.21$ and is not statistically significant. In rows five and six, we segment firms based on firm age defined relative to the first year that the firm appears on Compustat. We divide firms into two groups based on the sample median value of age. We expect young firms to face greater financing constraints. Consistent with this conjecture, the coefficient estimate on option proceeds for young firms is $\$ 0.37$ $(\mathrm{p}$-value $=0.04)$ compared to $\$ 0.30$ (p-value 0.03$)$ for old firms. Finally, the last two rows divide firms into two groups based on the median value of the Whited and $\mathrm{Wu}(2006)$ index of financial constraints. Higher values of the Whited-Wu index indicate more severe financial constraints. For the most constrained firms, the coefficient estimate associated with proceeds from option exercises is $\$ 0.37$ (p-value $=0.03)$, while, for less constrained firms, the coefficient estimate is $\$ 0.25$ ( $\mathrm{p}$-value $=0.23)$.

\section{Conclusion}

The paper investigates theoretically and empirically how stock-based compensation can relax financing constraints and affect investment. We show that stock options relax the financing constraints at the time of the grant and also provide significant inflows of cash at the time of exercise, conditional on high stock price. The state contingent nature of the cash flows associated with option exercises allows the firm to relax financing constraints and increase investment precisely in those states where the demand for investment is high. We also show that the state contingent nature of cash flows from exercise are an efficient mechanism for alleviating overinvestment problems.

We test the predictions of the model empirically and show that investment is increasing in the cash flows associated with option exercise, all else equal. Our 
estimates indicate that approximately $\$ 0.38$ of each dollar of proceeds received by the firm from the exercise of stock options is allocated to increasing capital and $\mathrm{R} \& \mathrm{D}$ expenditures. We also find that the sensitivity of investment to proceeds from exercise is higher in firms likely to face financing constraints. We find no evidence that firms divert funds from investment to repurchase shares to avoid dilution effects arising from stock option exercises as suggested by Bens et al. (2002).

Finally, although we focus on the relationship between investment and the proceeds from option exercise, the model suggests several other avenues for further research. Since cash inflows from stock options relax financing constraints, it would be interesting to study whether financially constrained firms with larger stock option programs raise less external funds in financing their new investment than similar firms without such programs. Additionally, it would be fruitful to investigate whether firms in which investment demand is more correlated with stock price grant more stock options to employees. Last, the model suggests that savings behavior is affected by the use of stock options and this could be investigated.

Overall, our analysis highlights an additional benefit of option-based compensation plans that has not been previously studied. Our results suggest that the role that options play in relaxing financing constraints is significant and should be considered when designing pay packages for employees. 


\section{Appendix A (proposition proofs)}

Proof of Proposition 1. Since constraints (9), (10), and (11) are not binding, the unconstrained firm makes first-best investment, i.e.,

$$
H^{\prime}\left(I_{1}^{H *}\right)=1, F^{\prime}\left(I_{0}^{*}\right)=1, L^{\prime}\left(I_{1}^{L *}\right)=1 .
$$

Clearly, in this case, investment is not sensitive to changes in the compensation structure, i.e.,

$$
\frac{\partial I_{1}^{H *}}{\partial n}=\frac{\partial I_{1}^{L *}}{\partial n}=\frac{\partial I_{0}^{*}}{\partial n}=0
$$

Proof of Proposition 2. The firm is not constrained in the low-demand state, but is constrained at $t=0$ and in the high-demand state at $t=1$. From (16) and (17),

$$
\begin{aligned}
\frac{\partial I_{0}^{*}}{\partial n} & =\frac{-1}{1-q} \frac{\partial w}{\partial n}-\frac{1}{1-q} \frac{\partial C^{*}}{\partial n} \\
& =\frac{1}{1-q} \frac{p H^{\prime \prime}\left(I_{1}^{H}\right)}{F^{\prime \prime}\left(I_{0}\right)+p H^{\prime \prime}\left(I_{1}^{H}\right)}\left(K-\frac{\partial w}{\partial n}\right) \\
\frac{\partial I_{1}^{H *}}{\partial n} & =\frac{1}{1-q}\left(\frac{\partial C^{*}}{\partial n}+K\right) \\
& =\frac{1}{1-q} \frac{F^{\prime \prime}\left(I_{0}\right)\left(K-\frac{\partial w}{\partial n}\right)}{F^{\prime \prime}\left(I_{0}\right)+p H^{\prime \prime}\left(I_{1}^{H}\right)},
\end{aligned}
$$

Since, from participation constraint (5), it follows that $\frac{\partial w}{\partial n}<0$, and since $q<$ 1 , and investment is characterized by decreasing returns to scale $H^{\prime \prime}\left(I_{1}^{H}\right)<$ $0, F^{\prime \prime}\left(I_{0}\right)<0$, it follows that

$$
\frac{\partial I_{0}^{*}}{\partial n}>0, \frac{\partial I_{1}^{H *}}{\partial n}>0
$$

i.e., whenever the firm is constrained, stock options help to relax constraints 
and finance more investment.

Proof of Proposition 3. In our setup, the firm chooses how much savings to carry to the next period after the compensation structure is already in place. To see that optimal savings decrease with a more severe agency problem, rewrite (23) as

$$
F^{\prime}\left(I_{0}\right)-p H^{\prime}\left(I_{1}^{H}\right)=(1-p) L^{\prime}\left(I_{1}^{L}\right)
$$

$L^{\prime}\left(I_{1}^{L}\right)$ decreases with more overinvestment, so that the LHS of (31) must also decrease. We show below that this implies that savings decrease.

If follows from (16) and (17) that $I_{0}$ decreases in savings, $C$, and $I_{1}^{H}$ increases in $C$. Moreover, since payoff functions $F\left(I_{0}\right)$ and $H\left(I_{1}^{H}\right)$ are concave in the argument, it follows that $F^{\prime}\left(I_{0}\right)$ and $H^{\prime}\left(I_{1}^{H}\right)$ decrease in the argument and

$$
\begin{aligned}
\frac{\partial F^{\prime}\left(I_{0}\right)}{\partial C} & =\frac{\partial F^{\prime}\left(I_{0}\right)}{\partial I} \frac{\partial I_{0}}{\partial C}>0 \\
\frac{\partial H^{\prime}\left(I_{1}^{H}\right)}{\partial C} & =\frac{\partial H^{\prime}\left(I_{1}^{H}\right)}{\partial I} \frac{\partial I_{1}^{H}}{\partial C}<0
\end{aligned}
$$

Then, it follows from (23) that the firm will respond to lower $L^{\prime}\left(I_{1}^{L}\right)$ (i.e., lower marginal profitability of the date 1 low-state investment) by decreasing the optimal savings, $C^{*}$. If the expected $t=1$ marginal profitability is sufficiently low, then the optimal amount of savings is zero.

Proof of Proposition 4. The first order condition with respect to savings is:

$$
\left(F^{\prime}-1\right) \frac{\partial I_{0}^{*}}{\partial n}+p\left(H^{\prime}-1\right) \frac{\partial I_{1}^{H *}}{\partial n}+(1-p)\left(L^{\prime}-1\right) \frac{\partial I_{1}^{L *}}{\partial n}-\left(1-\frac{p}{z}\right) \frac{\partial w}{\partial n}=0
$$

Note that, to determine how the overinvestment problem affects the compensation choice, we have to investigate the effect of $L^{\prime}$ on $n^{*}$. It follows from (22) 
and from (23) that

$$
\frac{\partial I_{1}^{L *}}{\partial n}=\frac{1}{1-q} \frac{\partial C^{*}}{\partial n}=\frac{1}{1-q} \frac{F^{\prime \prime} \frac{\partial w}{\partial n}+p K H^{\prime \prime}}{-\left(F^{\prime \prime}+p H^{\prime \prime}+(1-p) L^{\prime \prime}\right)} .
$$

If the probability of the high-demand state or the strike price of stock options

is sufficiently large, i.e. if $p K>\frac{\left|F^{\prime \prime} \frac{\partial w}{\partial n}\right|}{\left|H^{\prime \prime}\right|}$, then $\frac{\partial I_{1}^{L *}}{\partial n}<0$. In this case, the term $(1-p)\left(L^{\prime}-1\right) \frac{\partial I_{1}^{L *}}{\partial n}$ is positive and increases when $L^{\prime}$ decreases. Thus, whenever $L^{\prime}$ decreases, other terms in (34) must decrease for equality (34) still to hold. Note that $(1-p)\left(L^{\prime}-1\right) \frac{\partial I_{1}^{L *}}{\partial n}$ does not directly depend on $n^{*}$. Similarly, it follows from (5) that $\left(1-\frac{p}{z}\right) \frac{\partial w}{\partial n}$ does not directly depend on $n^{*}$. It must be then that, if $L^{\prime}$ decreases, the first two terms decrease. This is achieved by increasing the number of options $n^{*}$. Investment $I_{0}$ and $I_{1}^{H}$ increase with $n^{*}$, implying that $F^{\prime}$ and $H^{\prime}$ decrease with $n^{*}$ (because of decreasing returns to scale). Thus if $p K>\frac{\left|F^{\prime \prime} \frac{\partial w}{\partial n}\right|}{\left|H^{\prime \prime}\right|}$, with lower $L^{\prime}$, the optimal number of stock options in the compensation structure increases.

\section{Appendix B (case with nonzero corporate tax)}

Here, we discuss the case with positive corporate tax, $T$. Although the intuition is similar to the no-tax case, the analysis is complicated by the fact that the tax benefits from stock options depend on the stock price. Investment $I_{1}^{H}$ in this case is

$$
I_{1}^{H *}=\frac{1}{1-q}\left(c_{1}^{H}+C+n K+n\left(S^{H}-K\right) T\right) .
$$

Note that now expression for investment (35) contains and extra term $n\left(S^{H}-\right.$ $K) T$ since, at the time of exercise, stock options generate tax benefits and provide funds for investment. First resolve the circularity in the investment $I_{1}^{H}$ investment depends on stock price $S^{H}$ that in turn depends on the investment 
strategy. Substitute the stock price from (6):

$$
I_{1}^{H *}=\frac{1}{1-q}\left(c_{1}^{H}+C+n K+n\left(\frac{F\left(I_{0}^{*}\right)+H\left(I_{1}^{H *}\right)-q I_{0}^{*}-q I_{1}^{H *}}{n+N}-K\right) T\right),
$$

and differentiate with respect to amount of savings, $C$ :

$$
\begin{aligned}
\frac{\partial I_{1}^{H *}}{\partial C} & =\frac{1}{1-q}\left(1+\frac{n T}{n+N}\left(F^{\prime}-q\right) \frac{\partial I_{0}^{*}}{\partial C}+\frac{n T}{n+N}\left(H^{\prime}-q\right) \frac{\partial I_{1}^{H *}}{\partial C}\right) \\
\frac{\partial I_{1}^{H *}}{\partial C} & =\frac{1}{1-q} \frac{1-\frac{n T}{n+N}\left(F^{\prime}-q\right) \frac{1}{1-q}}{1-\frac{n T}{n+N}\left(H^{\prime}-q\right) \frac{1}{1-q}}=\frac{1}{1-q} G\left(n, I_{0}^{*}, I_{1}^{H *}\right) .
\end{aligned}
$$

Note that derivative $\frac{\partial I_{1}^{H *}}{\partial C}$ is equal to $\frac{1}{1-q}$, as in the no-tax case, times the factor $G\left(n, I_{0}^{*}, I_{1}^{H *}\right)$ that captures the feedback on the investment constraint through the stock price. In the case with positive corporate tax, expression (18) becomes

$$
\frac{F^{\prime}\left(I_{0}^{*}\right)-1}{1-q}=p\left(H^{\prime}\left(I_{1}^{H *}\right)-1\right) \frac{\partial I_{1}^{H *}}{\partial C}
$$

Totally differentiating expression (38), we obtain:

$$
\begin{aligned}
& \frac{\partial C^{*}}{\partial n}=-\frac{F^{\prime \prime} \frac{\partial w}{\partial n}+p H^{\prime \prime}(1-q)^{2} \frac{\partial I_{1}^{H}}{\partial n} \frac{\partial I_{1}^{H}}{\partial C}+p\left(H^{\prime}-1\right) \frac{\partial^{2} I_{1}^{H}}{\partial C \partial n}(1-q)^{2}}{F^{\prime \prime}+p H^{\prime \prime}\left(\frac{d I_{1}^{H}}{d C}\right)^{2}(1-q)^{2}+p\left(H^{\prime}-1\right) \frac{\partial^{2} I_{1}^{H}}{\partial C^{2}}(1-q)^{2}}(39) \\
= & -\frac{F^{\prime \prime} \frac{\partial w}{\partial n}+p H^{\prime \prime} A+E}{F^{\prime \prime}+p H^{\prime \prime} B+D}
\end{aligned}
$$

where $A, B, D$, and $E$ are the corrections for tax. Note that $A(T=0)=K$, $B(T=0)=1, D(T=0)=E(T=0)=0$. This recovers (19) in the text. 
Finally,

$$
\begin{aligned}
\frac{\partial I_{0}^{*}}{\partial n} & =\frac{1}{1-q}\left(-\frac{\partial C^{*}}{\partial n}-(1-T) \frac{\partial w}{\partial n}\right) \\
\frac{\partial I_{1}^{H *}}{\partial n} & =\frac{1}{1-q}\left(\frac{\partial C^{*}}{\partial n}+K+\left(S^{H}-K\right) T+n T \frac{\partial S^{H}}{\partial n}\right) .
\end{aligned}
$$

It is possible to show that both derivatives are positive under mild conditions. 


\section{References}

[1] Almeida, Heitor, Murillo Campello, and Michael S. Weisbach, 2004, The cash flow sensitivity of cash, Journal of Finance 59, 1777-1804.

[2] Alti, Aydogan, 2003, How sensitive is investment to cash flow when financing is frictionless? Journal of Finance 58, 707-722.

[3] Angrist, Joshua D., and Alan B. Krueger, 1999, Empirical strategies in labor economics, in Orley Ashenfelter, and David Card, eds.: Handbook of Labor Economics 3a (North-Holland, Amsterdam), 1277-1366.

[4] Angrist, Joshua D., and Victor Lavy, 1999, Using Maimonides' rule to estimate the effect of class size on student achievement, Quarterly Journal of Economics 114, 533-575.

[5] Babenko, Ilona, and Yuri Tserlukevich, 2007, Analyzing tax benefits from employee stock options, Working Paper, HKUST.

[6] Barclay, Michael J., Erwan Morellec, and Clifford W. Smith, 2006, On the capacity of the growth options, Journal of Business 79, 37-59.

[7] Brav, Alon, John R. Graham, Campbell Harvey, and Roni Michaely, 2005, Payout policy in the 21st Century, Journal of Financial Economics 77, 483-527.

[8] Bens, Daniel A., Venky Nagar, Daniel J. Skinner, and M.H. Franco Wong 2003, Employee stock options, EPS dilution, and stock repurchases, Journal of Accounting and Economics 36, 51-90.

[9] Bens, Daniel, A., Venky Nagar, and M.H. Franco Wong, 2002, Real investment implications of employee stock option exercises, Journal of Accounting Research 40, 359-393. 
[10] Bergman, Nittai, and Dirk Jenter, 2007, Employee Sentiment and Stock Option Compensation, Journal of Financial Economics 84, 667-712.

[11] Bizjak, John M., James A. Brickley, and Jeffrey L. Coles, 1993, Stock-based incentive compensation and investment behavior, Journal of Accounting and Economics 16, 349-372.

[12] Bettis, Carr J., John M. Bizjak, and Michael Lemmon, 2005, Exercise behavior, valuation, and the incentive effects of employee stock options, Journal of Financial Economics 76, 446-470.

[13] Carpenter 1998

[14] Cleary, Sean, 1999, The relationship between firm investment and financial status, Journal of Finance 54, 673-692.

[15] Core, John E., and Wayne R. Guay, 2001, Stock option plans for nonexecutive employees, Journal of Financial Economics 61, 253-287.

[16] Erickson, Timothy, and Toni M. Whited, 2000, Measurement error and the relationship between investment and q, Journal of Political Economy 108, $1027-1057$.

[17] Fama, Eugene F., and Kenneth R. French, 2004, Financing decisions: who issues stock? Journal of Financial Economics 76, 549-582.

[18] Froot, Kenneth A., David S. Sharfstein, and Jeremy Stein, 1993, Risk management: coordinating corporate investment and financing policies, Journal of Finance 48, 1629-1658.

[19] Gomes, Joao, 2001, Financing investment, American Economic Review 91, $1263-1285$. 
[20] Graham, John, 1996, Debt and the marginal tax rate, Journal of Financial Economics 41, 41-73.

[21] Graham, John R., Mark H. Lang, and Douglas Shackelford, 2004, Employee stock options, corporate taxes and debt policy, Journal of Finance 59, 15851618.

[22] Hanlon, Michelle, and Terry Shevlin, 2002, Accounting for the tax benefits of employee stock options and implications for research, Accounting Horizons 16, 1-16.

[23] Hall, Brian J., and Jeffrey B. Liebman, 1998, Are CEOs really paid like bureaucrats? Quarterly Journal of Economics 113, 653-691.

[24] Hall, Brian J., and Kevin J. Murphy, 2002, Stock options for undiversified executives, Journal of Accounting and Economics 33, 3-42.

[25] Hall, Brian J., and Kevin J. Murphy, 2003, The trouble with stock options, Journal of Economic Perspectives 17, 49-70.

[26] Heath, Chip, Steven Huddart, and Mark Lang, 1999, Psychological factors and stock option exercise, Quarterly Journal of Economics 114, 601-627.

[27] Himmelberg, Charles P., and Bruce C. Petersen, 1994, R \& D and internal finance: a panel study of small firms in high-tech industries, Review of Economics and Statistics 76, 38-51.

[28] Hong, Harrison, Wang, Jiang, and Jialin Yu, 2007, Firms as buyers of last resort: financing constraints, stock returns and liquidity, Unpublished working paper, Princeton, MIT and Columbia Universities.

[29] Huddart, Steven, and Mark Lang, Information distribution within firms: evidence from stock option exercises, Journal of Accounting and Economics 34, 3-31. 
[30] Jensen, Michael C., 1986, Agency costs of free cash flow, corporate finance and takeovers, American Economic Review 76, 323-329.

[31] Ittner, Christopher D., Richard A. Lambert, and David F. Larcker, 2003, The structure and performance consequences of equity grants to employees of new economy firms, Journal of Accounting and Economics 34, 89-127.

[32] Kahle, Kathleen M., 2002, When a buyback isn't a buyback: open market repurchases and employee options, Journal of Financial Economics 63, 235261.

[33] Kaplan and Zingales 1997

[34] Kato, Hideaki Kiyoshi, Michael Lemmon, Mi Luo, and James Schallheim, 2005, An empirical examination of the costs and benefits of executive stock options: evidence from Japan, Journal of Financial Economics 78, 435-461.

[35] Mayers, David, 1998, Why firms issue convertible bonds: the matching of financial and real investment options, Journal of Financial Economics 47, 83-102.

[36] Moyen, Nathalie, 2004, Investment-cash flow sensitivities: constrained versus unconstrained firms, Journal of Finance 59, 2061-2092.

[37] Murphy, Kevin, 1999, Executive compensation, in Handbook of Labor Economics 3b, Ashenfelter and Card eds., Amsterdam, North Holland, 24852563.

[38] Myers, Stewart, and Nicholas Majluf, 1984, Corporate financing and investment decisions when firms have information that investors do not have, Journal of Financial Economics 13, 187-221.

[39] Oyer, Paul, 2004, Why do firms use incentives that have no incentive effects? Journal of Finance 59, 1619-1649. 
[40] Oyer, Paul, and Scott Schaefer, 2005a, Why do some firms give stock options to all employees?: An empirical examination of alternative theories, Journal of Financial Economics 76, 99-133.

[41] Oyer, Paul, and Scott Schaefer, 2005b, Costs of broad-based stock option plans, Journal of Financial Intermediation 15, 511-534.

[42] Rauh, Joshua D., 2006, Investment and financing constraints: evidence from the funding of corporate pension plans, Journal of Finance 61, 33-72.

[43] Shleifer, Andrei, and Robert W. Vishny, 1990, The takeover wave of the 1980s, Science 249, 745-749.

[44] Stein, Jeremy C. 1992, Convertible bonds as backdoor equity financing, Journal of Financial Economics 32, 3-21.

[45] Tserlukevich, Yuri, 2007, Can real options explain financing behavior? forthcoming, Journal of Financial Economics.

[46] Van der Klaauw, Wilbert, 1996, Female labour supply and marital status decisions: a life-cycle model, Review of Economic Studies 63, 199-235.

[47] Whited, Tony, and Guojun Wu, 2006, Financial constraints risk, Review of Financial Studies 19, 531-559.

[48] Yermack, David, 1995, Do corporations award CEO stock options effectively? Journal of Financial Economics 39, 237-269. 


\section{Table I. Descriptive Statistics.}

The sample consists of S\&P 500 and NASDAQ 100 firms during the period of 1999-2005 and excludes financial and utilities companies. Assets are the total firm's assets; Cash Flow is equal to the sum of income before extraordinary items, depreciation and amortization, and research and development expenses, all normalized by the beginning-of-year book assets; $Q$ is equal to the market capitalization plus book assets minus book equity and minus deferred taxes all taken at the beginning-of-year, divided by the beginning-of-year book assets; CAPEX/Assets is the firm's capital expenditures normalized by the beginning-of-year book assets; $R \mathscr{E} D / A$ ssets is the firm's research and development expenses normalized by the beginning-of-year book assets; Total Investment/Assets is the sum of CAPEX/Assets and RED/Assets; Stock Repurchases/Assets is the dollar amount spent on repurchases normalized by the beginningof-year book assets; Option Proceeds are equal to the number of options exercised during the fiscal year, multiplied by the weighted average strike price of options exercised; Tax Benefits are equal to the number of options exercised during the fiscal year, multiplied by the difference between year-end stock price and the weighted average strike price of option exercised, and by the corporate marginal tax rate; Option Grants are equal to the Black-Scholes value (adjusted for dividend payout) of options granted during the fiscal year, where the maturity of options is set to the expected option term as disclosed in firm's 10-K forms; Option Use is the number of outstanding stock options normalized by the number of firm's outstanding shares. High (Low) Option Users are firms with the Option Use above (below) the sample median, respectively.

\begin{tabular}{lccccc}
\hline \multicolumn{7}{c}{ Panel A: Full Sample } & & & \\
\hline Variable & Mean & Std. Dev. & $25 \%$ & $50 \%$ & $75 \%$ \\
\hline Assets $(\$ M)$ & 14,076 & 37,170 & 2,103 & 5,050 & 14,391 \\
Cash Flow/Assets & 0.154 & 0.124 & 0.083 & 0.137 & 0.206 \\
Q & 2.686 & 2.327 & 1.249 & 1.846 & 3.149 \\
CAPEX/Assets & 0.062 & 0.053 & 0.027 & 0.047 & 0.077 \\
R\&D/Assets & 0.034 & 0.058 & 0 & 0.003 & 0.044 \\
Total Investment/Assets & 0.097 & 0.080 & 0.045 & 0.073 & 0.122 \\
Stock Repurchases/Assets & 0.033 & 0.057 & 0 & 0.006 & 0.041 \\
Option Proceeds/Assets & 0.013 & 0.021 & 0.002 & 0.006 & 0.015 \\
Tax Benefits/Assets & 0.012 & 0.048 & 0.000 & 0.001 & 0.005 \\
Option Grants/Assets & 0.059 & 0.128 & 0.008 & 0.020 & 0.055 \\
Option Proceeds $(\$ M)$ & 76.41 & 149.54 & 9.04 & 28.32 & 75.97 \\
Tax Benefits $(\$ M)$ & 55.14 & 252.30 & 0.52 & 4.63 & 27.09 \\
Option Grants $(\$ M)$ & 315.14 & 828.62 & 44.49 & 102.88 & 263.92 \\
Option Use & 0.125 & 0.163 & 0.060 & 0.092 & 0.145 \\
\hline
\end{tabular}




\begin{tabular}{|c|c|c|c|c|c|}
\hline \multicolumn{6}{|c|}{ Panel B: High Option Users } \\
\hline Variable & Mean & Std. Dev. & $25 \%$ & $50 \%$ & $75 \%$ \\
\hline Assets $(\$ M)$ & 11,755 & 35,022 & 1,538 & 3,439 & 10,171 \\
\hline Cash Flow/Assets & 0.169 & 0.139 & 0.088 & 0.152 & 0.228 \\
\hline Q & 2.985 & 2.646 & 1.338 & 2.082 & 3.458 \\
\hline CAPEX/Assets & 0.059 & 0.056 & 0.022 & 0.041 & 0.073 \\
\hline R\&D/Assets & 0.050 & 0.069 & 0 & 0.021 & 0.079 \\
\hline Total Investment/Assets & 0.110 & 0.092 & 0.047 & 0.087 & 0.142 \\
\hline Stock Repurchases/Assets & 0.037 & 0.060 & 0 & 0.009 & 0.049 \\
\hline Option Proceeds/Assets & 0.019 & 0.026 & 0.003 & 0.009 & 0.022 \\
\hline Tax Benefits/Assets & 0.020 & 0.065 & 0.000 & 0.002 & 0.011 \\
\hline Option Grants/Assets & 0.092 & 0.168 & 0.015 & 0.037 & 0.090 \\
\hline Option Proceeds $(\$ \mathrm{M})$ & 81.64 & 153.61 & 11.48 & 34.12 & 80.87 \\
\hline Tax Benefits $(\$ M)$ & 80.50 & 343.12 & 0.79 & 6.73 & 38.88 \\
\hline Option Grants $(\$ M)$ & 380.33 & 960.06 & 59.46 & 135.22 & 334.45 \\
\hline Option Use & 0.193 & 0.207 & 0.112 & 0.145 & 0.199 \\
\hline \multicolumn{6}{|c|}{ Panel C: Low Option Users } \\
\hline Variable & Mean & Std. Dev. & $25 \%$ & $50 \%$ & $75 \%$ \\
\hline Assets $(\$ M)$ & 16,397 & 39,078 & 2,987 & 7,689 & 17,839 \\
\hline Cash Flow/Assets & 0.141 & 0.105 & 0.079 & 0.125 & 0.183 \\
\hline Q & 2.387 & 1.913 & 1.199 & 1.661 & 2.873 \\
\hline CAPEX/Assets & 0.065 & 0.050 & 0.032 & 0.051 & 0.080 \\
\hline R\&D/Assets & 0.018 & 0.038 & 0 & 0 & 0.022 \\
\hline Total Investment/Assets & 0.084 & 0.063 & 0.044 & 0.067 & 0.103 \\
\hline Stock Repurchases/Assets & 0.028 & 0.052 & 0 & 0.005 & 0.034 \\
\hline Option Proceeds/Assets & 0.008 & 0.013 & 0.001 & 0.003 & 0.010 \\
\hline Tax Benefits/Assets & 0.004 & 0.019 & 0.000 & 0.000 & 0.003 \\
\hline Option Grants/Assets & 0.025 & 0.050 & 0.004 & 0.012 & 0.029 \\
\hline Option Proceeds $(\$ \mathrm{M})$ & 71.17 & 145.22 & 7.38 & 24.15 & 68.93 \\
\hline Tax Benefits $(\$ M)$ & 31.40 & 109.22 & 0.34 & 3.18 & 19.31 \\
\hline Option Grants (\$M) & 249.95 & 666.01 & 32.97 & 78.46 & 202.21 \\
\hline Option Use & 0.057 & 0.023 & 0.037 & 0.060 & 0.078 \\
\hline
\end{tabular}


Table II. Fixed Effects Regressions of Investment on Stock Option Proceeds and Cash Inflows.

The dependent variables are capital expenditures normalized by the beginning-ofyear book assets $(C A P E X)$, research and development expenses normalized by the beginning-of-year book assets $(R \mathcal{G} D)$, the sum of these two variables (Total Invest), and stock repurchases normalized by the beginning-of-year book assets (Stock Rep). Option Proceeds are equal to the number of options exercised during the fiscal year, multiplied by the weighted average strike price of options exercised and normalized by the beginning-of-year book assets; Tax Benefits are equal to the number of options exercised during the fiscal year, multiplied by the difference between year-end stock price and the weighted average strike price of options exercised, and by the corporate marginal tax rate; Option Cash Inflow is equal to the sum of Option Proceeds and Tax Benefits; Moneyness is equal to the market-to-strike ratio of outstanding options; Cash Flow is equal to the sum of income before extraordinary items, depreciation and amortization, and research and development expenses, all normalized by the beginning-of-year book assets; $\mathrm{Q}$ is equal to the market capitalization plus book assets minus book equity and deferred taxes all taken at the beginning-of-year, divided by the beginning-of-year book assets. The estimation includes fixed year- and firmeffects. P-values based on Huber-White standard errors (clustered by firm) are listed in parentheses. Significance at the $1 \%, 5 \%$, and $10 \%$ level is denoted by ${ }^{* * *},{ }^{* *}$, and *, respectively.

\begin{tabular}{|c|c|c|c|c|c|c|c|}
\hline & \multicolumn{7}{|c|}{ Dependent Variables } \\
\hline & $\begin{array}{l}\text { Total } \\
\text { Invest. }\end{array}$ & CAPEX & $\mathrm{R} \& \mathrm{D}$ & $\begin{array}{l}\text { Stock } \\
\text { Rep. }\end{array}$ & $\begin{array}{l}\text { Total } \\
\text { Invest. }\end{array}$ & $\begin{array}{l}\text { Total } \\
\text { Invest. }\end{array}$ & $\begin{array}{l}\text { Total } \\
\text { Invest. }\end{array}$ \\
\hline Cash Flow & $\begin{array}{l}0.193^{* * *} \\
(0.000)\end{array}$ & $\begin{array}{l}0.104^{* * *} \\
(0.000)\end{array}$ & $\begin{array}{l}0.077^{* * *} \\
(0.000)\end{array}$ & $\begin{array}{l}0.036^{*} \\
(0.090)\end{array}$ & $\begin{array}{l}0.189^{* * *} \\
(0.000)\end{array}$ & $\begin{array}{l}0.178^{* * *} \\
(0.000)\end{array}$ & $\begin{array}{l}0.185^{* * *} \\
(0.000)\end{array}$ \\
\hline $\mathrm{Q}$ & $\begin{array}{l}0.007^{* * *} \\
(0.000)\end{array}$ & $\begin{array}{l}0.005^{* * *} \\
(0.000)\end{array}$ & $\begin{array}{l}0.003^{* * *} \\
(0.002)\end{array}$ & $\begin{array}{l}0.002 \\
(0.176)\end{array}$ & $\begin{array}{l}0.007^{* * *} \\
(0.000)\end{array}$ & $\begin{array}{l}0.006^{* * *} \\
(0.000)\end{array}$ & $\begin{array}{l}0.007^{* * * *} \\
(0.000)\end{array}$ \\
\hline $\begin{array}{l}\text { Option } \\
\text { Proceeds }\end{array}$ & $\begin{array}{l}0.381^{* * *} \\
(0.009)\end{array}$ & $\begin{array}{l}0.188^{*} \\
(0.083)\end{array}$ & $\begin{array}{l}0.271^{* * *} \\
(0.000)\end{array}$ & $\begin{array}{l}-0.071 \\
(0.602)\end{array}$ & $\begin{array}{l}0.326^{* *} \\
(0.027)\end{array}$ & $\begin{array}{l}0.345^{*} \\
(0.055)\end{array}$ & \\
\hline Moneyness & & & & & $\begin{array}{l}-0.001 \\
(0.714)\end{array}$ & & \\
\hline Moneyness $^{2}$ & & & & & $\begin{array}{l}0.0004 \\
(0.165)\end{array}$ & & \\
\hline Tax Benefits & & & & & & $\begin{array}{l}0.073^{*} \\
(0.093)\end{array}$ & \\
\hline $\begin{array}{l}\text { Option Cash } \\
\text { Inflow }\end{array}$ & & & & & & & $\begin{array}{l}0.114^{* * * *} \\
(0.006)\end{array}$ \\
\hline Adjusted $R^{2}$ & 0.787 & 0.717 & 0.898 & 0.530 & 0.789 & 0.800 & 0.799 \\
\hline Observations & 2,298 & 2,298 & 2,298 & 2,120 & 2,298 & 1,820 & 1,820 \\
\hline
\end{tabular}


Table III. Fixed Effects Regressions of Investment on Stock Option Proceeds Segmented by Measures of Financing Constraints.

The dependent variable is the sum of capital expenditures and research and development expenses normalized by the beginning-of-year book assets (Total Invest). Option Proceeds are equal to the number of options exercised during the fiscal year, multiplied times the weighted average strike price of options exercised and normalized by the beginning-of-year book assets; Cash Flow is equal to the income before extraordinary items plus depreciation and amortization plus research and development expenses, normalized by the beginning-of-year book assets; $Q$ is equal to the market capitalization plus book assets minus book equity and deferred taxes all taken at the beginning-of-year, divided by the beginning-of-year book assets. The estimation includes fixed year- and firm-effects. $\mathrm{P}$-values based on Huber-White standard errors (clustered by firm) are listed in parentheses. Significance at the 1\%,5\%, and $10 \%$ level is denoted by $* * *, * *$, and $*$, respectively.

\begin{tabular}{|c|c|c|c|c|c|}
\hline \multicolumn{6}{|c|}{ Dependent Variable is Total Investment } \\
\hline \multirow[t]{3}{*}{ Financing Constraints } & \multicolumn{5}{|c|}{ Independent variables } \\
\hline & Cash & Q & Option & Obs. & Adj. $R^{2}$ \\
\hline & Flow & & Proceeds & & \\
\hline \multicolumn{6}{|l|}{ 1. Dividend Payout } \\
\hline \multirow[t]{2}{*}{ Zero Dividends } & $0.182^{* * *}$ & $0.006^{* * *}$ & $0.479^{* *}$ & 818 & 0.760 \\
\hline & $(0.000)$ & $(0.000)$ & $(0.028)$ & & \\
\hline \multirow[t]{2}{*}{ Positive Dividends } & $0.216^{* * *}$ & $0.008^{* *}$ & 0.180 & 1,480 & 0.789 \\
\hline & $(0.000)$ & $(0.017)$ & $(0.158)$ & & \\
\hline \multicolumn{6}{|l|}{ 2. Bond Ratings } \\
\hline \multirow[t]{2}{*}{ Below Inv. Grade } & $0.182^{* * *}$ & $0.007^{* * *}$ & $0.441^{* *}$ & 789 & 0.774 \\
\hline & $(0.000)$ & $(0.000)$ & $(0.036)$ & & \\
\hline \multirow[t]{2}{*}{ Inv. Grade and Above } & $0.219^{* * *}$ & $0.005^{* * *}$ & 0.213 & 1,509 & 0.780 \\
\hline & $(0.000)$ & $(0.003)$ & $(0.123)$ & & \\
\hline \multicolumn{6}{|l|}{ 3. Firm Age } \\
\hline \multirow[t]{2}{*}{ Young Firms } & $0.208^{* * *}$ & $0.007^{* * *}$ & $0.372^{* *}$ & 1,134 & 0.771 \\
\hline & $(0.000)$ & $(0.000)$ & $(0.042)$ & & \\
\hline \multirow[t]{2}{*}{ Old Firms } & $0.155^{* * *}$ & $0.005^{* *}$ & $0.304^{* *}$ & 1,164 & 0.767 \\
\hline & $(0.001)$ & $(0.017)$ & $(0.029)$ & & \\
\hline \multicolumn{6}{|l|}{ 4. Whited-Wu Index } \\
\hline \multirow[t]{2}{*}{ High Index } & $0.188^{* * *}$ & $0.006^{* * *}$ & $0.371^{* *}$ & 1,113 & 0.785 \\
\hline & $(0.000)$ & $(0.000)$ & $(0.026)$ & & \\
\hline \multirow[t]{2}{*}{ Low Index } & $0.241^{* * *}$ & $0.009^{* * *}$ & 0.246 & 1,113 & 0.784 \\
\hline & $(0.000)$ & $(0.008)$ & $(0.235)$ & & \\
\hline
\end{tabular}

